\title{
Weight-Length Relationships of Seven Fish Species (Teleostei: Sparidae, Mullidae, Carangidae) of Western Mediterranean Sea (Oran Bay, Algeria)
}

\author{
Lotfi Bensahla Talet ${ }^{*}$, Malika Gherram ${ }^{2}$ and Ahmed Bensahla Talet ${ }^{2}$
}

${ }^{1}$ University of Oran1 Ahmed BENBELLA Laboratoire Réseau de Surveillance Environnementale (L.R.S.E), Faculty of Natural Sciences and Life. Department of Biology. Es-sénia 31000 Oran Algeria

${ }^{2}$ University of Oran1 Ahmed BENBELLA. Laboratoire d'Aquaculture et de Bio remédiation (Aquabior), Faculty of Natural Sciences and Life, Department of Biology. Es-sénia, 31000 Oran. Algeria

*btlotfi77@hotmail.fr

\begin{abstract}
No information currently exists on the weight-length relationships of Sparidae: Axillary seabream Pagellus acarne (Risso, 1827), bogue Boops boops (Linnaeus, 1758); Mullidae: Red mullet Mullus barbatus (Linnaeus, 1758), surmulet Mullus surmuletus (Linnaeus, 1758) and Carangidae: Atlantic horse mackerel Trachurus trachurus (Linnaeus,1758), Mediterranean horse mackerel Trachurus mediterraneus (Steindachner 1863), Blue jack mackerel Trachurus picturatus (Bowdich 1825), seven commercial fish species of Oran Bay in Western Mediterranean Sea. Data are presented for the first time for that region of the Mediterranean Sea to contribute and help comparative growth studies. Samples were collected from commercial catches at Oran Bay fisheries in Algeria. The values of the slope $b$ in the lengthweight relationship, $\mathrm{W}=\mathrm{aL}^{\mathrm{b}}$ ranged from 2.841 to 3.296 . The coefficients of correlation $\mathrm{r}^{2}$ were comprised between 0.85 and 0.97 . "a" and "b" parameters were compared with other fishing sites for the same fish species with Froese plot $[\log a=f(b)]$.

Keywords: Weight-Length relationship; Pagellus acarne; Boops boops; Mullus barbatus; Mullus surmuletus; Trachurus trachurus; Trachurus mediterraneus; Trachurus picturatus; Oran Bay, Algeria.
\end{abstract}

\section{Introduction}

Oran Bay provides a significant proportion of the olverall marine fish production in Algeria and is considered as one of the most important fishery grounds in Algerian coasts (Bensahla Talet and Boutiba, 2000). Sparidae, Mullidae and Carangidae are three fish families widely consumed by local people. In this study, we targeted seven species from those families: Pagellus acarne, Boops boops, Mullus barbatus, Mullus surmuletus, Trachurus trachurus, Trachurus mediteraneus and Trachurus picturatus because they represent the most dominant species caught from Oran Bay.

Many studies have been already done concerning the weight-length relationships: 40 fish species from Greek waters (Moutopoulos and Stergiou, 2002); 39 species from Turkish waters (Sangun et al., 2007). For Algerian 
waters, some works have already been done on B. boops (Chali-Chabane, 1988 in Djabali et al., 1993); T. mediterraneus; T. trachurus (Korichi, 1988 in Djabali et al., 1993) but to our knowledge no such study was done for $P$. acarne, $M$. barbatus, $M$. surmuletus and Trachurus picturatus about WLRs (WeightLength Relationships) so our aim is to remedy this deficiency and providing the missing data. Length-weight regressions have been used frequently to estimate weight from length because direct weight measurements can be time-consuming in the field (Sinovcic et al., 2004). In sampling programs, it is usually easier to measure length because of bobbing motion of the fishing boat, than weight. Also, weight cannot be measured easily in underwater visual censuses (Morey et al., 2003). These data are essential to estimate growth rates, length and age structures (Kolher et al., 1995) and also to other components like conversion of growth in length to growth in weight (Pauly, 1993). Also, this relationship provides useful tool for fish species dynamics and allows morphological comparison between fish populations in a given geographic region in relation to different environmental scenarios (Gonçalves et al., 1997; Ritcher et al., 2000).

\section{Material and Methods}

A total of 4.070 fish specimens were collected for the three fish families: Sparidae, Mullidae and Carangidae. Samples of $P$. acarne, B.boops, $M$. barbatus, $M$. surmuletus, $T$. trachurus, T. mediteraneaus and T. picturatus were obtained from fish landings in Oran Bay (Fig.1) between April 2008 and August 2011, mainly caught using midwater and bottom trawl at depths ranging from 130 to $350 \mathrm{~m}$.

The most abundant species in the present study was T. mediteraneus (1.795), followed by $P$. acarne with (844) individuals, T. trachurus (769), M. barbatus (369), B. boops (111), T. picturatus (94) and M. surmuletus, (88).
Specimens were measured to the nearest $1 \mathrm{~mm}$ (total length, $\mathrm{L}_{t}$ ) and weighed to the nearest $0.1 \mathrm{~g}$ (weight, $\mathrm{W}_{\mathrm{t}}$ ). The relationship between weight and length of a fish is usually expressed by the equation $\mathrm{W}=\mathrm{aL}^{\mathrm{b}}$ (Ricker, 1973) where $\mathrm{W}$ is the body weight (g), $\mathrm{L}$ is the total length $(\mathrm{cm})$, "a" is the intercept and " $b$ " is the slope (allometry coefficient) (Beverton and Holt, 1996). The parameters "a" and "b" of the weight-length relationships were estimated by the least-square method from logarithmically transformed data to correct for non-linearity and heterogeneous variances: $\log \mathrm{W}_{\mathrm{t}}=\mathrm{b} \log \mathrm{L}_{\mathrm{t}}+\log \mathrm{a}$.

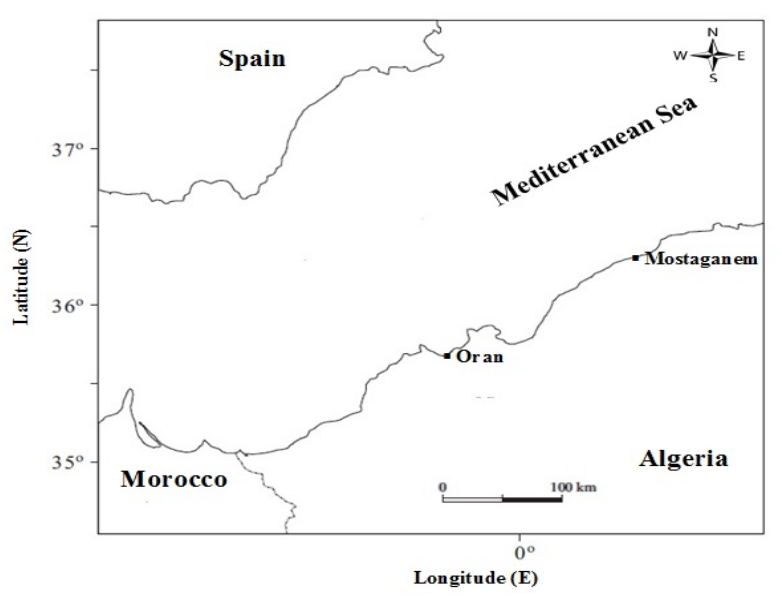

Fig. 1. Map of Study Area showing location of Oran Bay.

The association degree between weight-length variables was calculated by the determination coefficient $\left(r^{2}\right)$ and analyzed with ANOVA. Values of the exponent " $b$ " provide information on fish growth. If $b=3$, so increase in weight is isometric. When the value of " $b$ " is other than 3, so weight increase is allometric, (positive allometric if $b>3$, or negative allometric if $b<3$ ). The null hypothesis of the isometric growth $\left(\mathrm{H}_{0}: \mathrm{b}=3\right)$ was tested by $\mathrm{t}$-test, using the statistic formula: $t s=(b-3) / \mathrm{Sb}$, where $\mathrm{S}_{\mathrm{b}}$ is the standard error of the slope, for $\alpha=0.05$ (Morey et al., 2003). All calculations were done using Microsoft EXCEL $2007^{\circ}$ and STATISTICA $6.0^{\odot}$ software. It is important to highlight that 
our data are not representative of a particular time or period of the year and for comparison purposes are considered only as mean annual. Froese (2000) has suggested that plotting of $\log a$ versus b (Fig. 3) for all known weightlength relationships of a species results in a linear relationship, and that this relationship can be used to identify outliers. In this paper, we have applied this method to all species.
Table 1 shows the results of W-L relationship for the fish species studied. The sample varied between 88 to 1795 specimens and $b$ values varied between 2.842 and 3.296. All relationships were highly significant (ANOVA, $\mathrm{P}<0.001$ ) and $\mathrm{r}^{2}$ values ranged from 0.854 to 0.978 indicating a positive correlation between total weight $\left(\mathrm{W}_{\mathrm{t}}\right)$ and total length (L)

\section{Results}

Table 1. Estimated parameters of the weight-length relationship $\left(W=a L^{b}\right)$ for seven fishes from Oran Bay (Algeria). (W in g, $\mathrm{L}$ in $\mathbf{~ c m})$.

\begin{tabular}{|l|c|c|c|c|c|c|c|}
\hline \multicolumn{1}{|c|}{ Species } & $\mathbf{n}$ & $\mathbf{L}_{\mathbf{t}}(\mathbf{m i n}-\mathbf{m a x})$ & $\mathbf{W}_{\mathbf{t}}(\mathbf{m i n}-\mathbf{m a x})$ & $\mathbf{a}$ & $\mathbf{b} \pm \mathbf{s . e}(\mathbf{b})$ & $\mathbf{r}^{\mathbf{2}}$ & Growth \\
\hline Pagellus acarne & 844 & $11.9-26.3$ & $27.0-234.0$ & 0.00890 & $3.100 *_{ \pm} 0.020$ & 0.959 & + allometric \\
\hline Boops boops & 111 & $14.4-24.0$ & $25.9-123.1$ & 0.00504 & $3.192 *_{ \pm} 0.029$ & 0.94 & + allometric \\
\hline Mullus barbatus & 369 & $10.9-23.2$ & $20.4-149.2$ & 0.01670 & $2.842 * \pm 0.028$ & 0.854 & - allometric \\
\hline Mullus surmuletus & 88 & $12.0-22.5$ & $20.7-109.7$ & 0.01070 & $2.970 \pm 0.043$ & 0.978 & 0 isometric \\
\hline Trachurus picturatus & 94 & $13.8-20.3$ & $18.7-60.70$ & 0.00458 & $3.161 *_{ \pm} 0.015$ & 0.962 & + allometric \\
\hline Trachurus mediterraneus & 1795 & $13.2-35.0$ & $16.9-344.4$ & 0.00589 & $3.094 \pm 0.030$ & 0.948 & + allometric \\
\hline Trachurus trachurus & 769 & $14.2-23.5$ & $20.7-97.70$ & 0.00310 & $3.296 * 0.027$ & 0.932 & + allometric \\
\hline
\end{tabular}

n: sample size, a: intercept, b: slope, s.e (b): standard error of $\mathbf{b}, \mathbf{r}^{2}$ :coefficient of determination, ${ }^{*}$ :significant $t$-test $(\mathrm{P}<0.05)$.

\section{Discussion}

The comparison of $b$ values for the species appearing both in this study and those obtained by other authors in the Mediterranean Sea had suggested inter-regional differences. " $b$ " values for $P$. acarne ranged from 2.84 to 3.26 , for $B$. boops from 2.87 to 3.19 , for $M$. barbatus from 2.83 to 3.28 , for $M$. surmuletus from 2.97 to $3.25, T$. picturatus from 3.04 to 3.16, T. mediterraneus from 2.82 to 3.30 and T. trachurus from 3.27 to 3.29 .

W-L relationships parameters can vary between stocks and even between areas as stated by (Sparre et al., 1989; Andrade and Campos, 2002). These differences in b-values can be attributed to the combination of one or more of the following factors: a) differences in the number of specimen examined, b) area/season effect and c) differences in the observed length ranges of the specimen caught. Dulcic and Kraljevic (1998) stated that temperature, food quantity, quality and size), sex and stage of maturity are responsible for the differences in parameters of WL relationship. In addition, Froese (2006) stated that small specimens have a different WLR relationship than larger specimens.

Concerning the type of growth, isometric growth was found in $M$. surmuletus, negative allometry for $M$. barbatus, and positive allometry in Sparidae: $P$. acarne, B. boops and carrangidae: T. picturatus, $T$. mediterraneus, T. trachurus (Fig. 2). All relationships were significant (t-test, $\mathrm{P}<0.05$ ) except for $M$. surmuletus. 

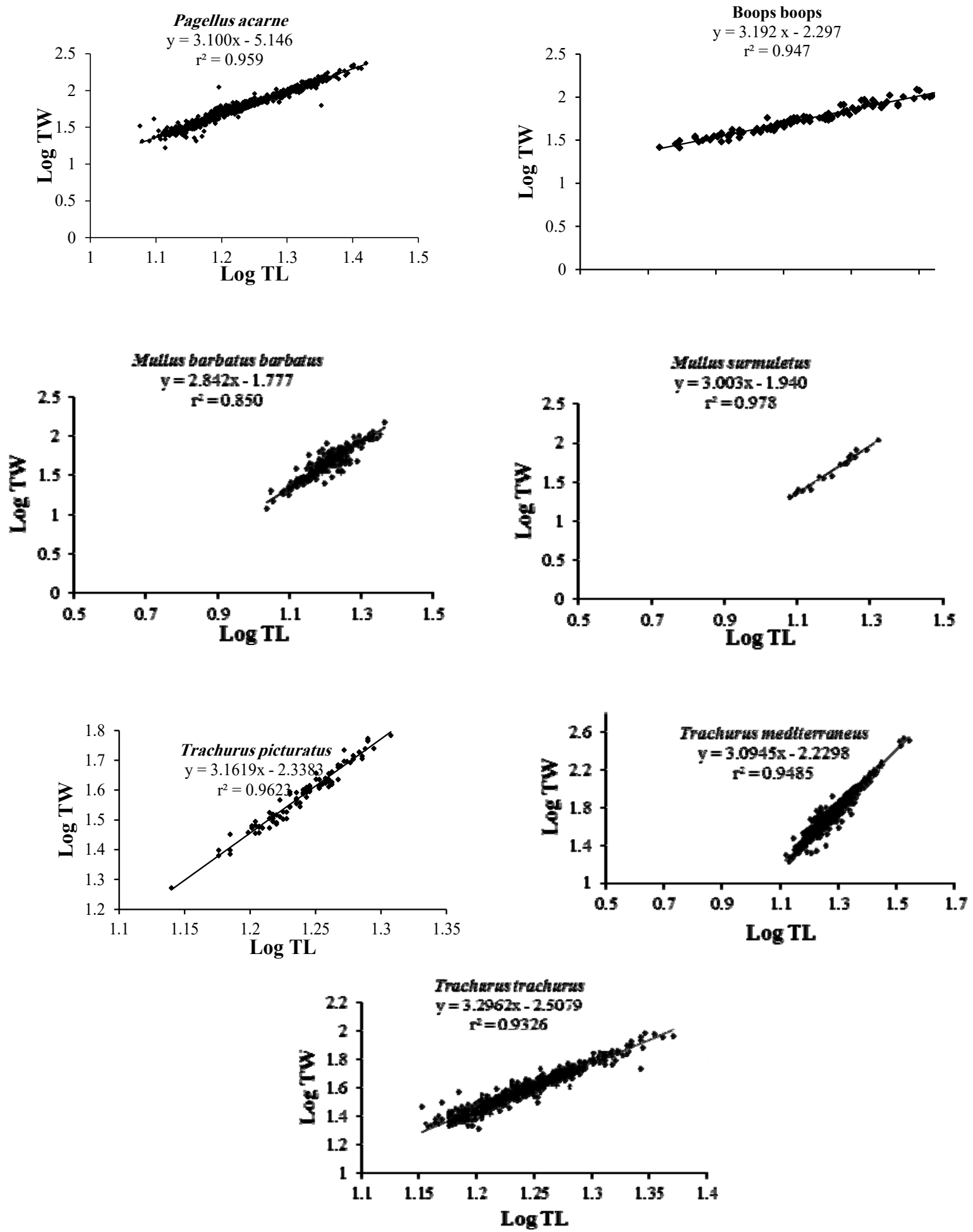

Fig. 2. Weight-length relationships for seven fish species from the W. Mediterranean Sea (Oran Bay-Algeria). 
Table 2. Estimated parameters for the Weight-Length relationship $\left(\mathrm{W}=\mathrm{aL}^{\mathrm{b}}\right)$ for $P$. acarne, B. boops, $M$. barbatus, $M$. surmuletus, T. picturatus, T. mediterraneus and T. trachurus given by several authors. (W in $\mathrm{g}, \mathrm{L}$ in $\mathrm{cm}$ ).

\begin{tabular}{|c|c|c|c|c|c|c|c|c|c|}
\hline & Author & Locality & $\mathbf{n}$ & Lt & $\mathbf{W t}$ & $\mathbf{a}$ & $\mathbf{b} \pm \operatorname{se}(\mathbf{b})$ & $\mathbf{r}^{2}$ & All \\
\hline \multirow{4}{*}{ 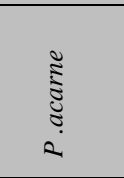 } & Present study & Oran Bay Algeria & 844 & $11.9-26.3$ & $27-234$ & 0.0089 & $3.10 \pm 0.020$ & 0.95 & + \\
\hline & Ceyhan et al., 2009 & Turkey & 46 & $12.1-16.5$ & - & 0.0094 & $3.26 \pm 0.11$ & 0.95 & + \\
\hline & Sangun et al., 2007 & Turkey & 83 & $11.0-17.0$ & $16.49-57.43$ & 0.0186 & $2.84 \pm 0.146$ & 0.91 & - \\
\hline & $\begin{array}{l}\text { Moutopoulos and } \\
\text { Stergiou, } 2002\end{array}$ & $\begin{array}{l}\text { Kyclades } \\
\text { Greece }\end{array}$ & 96 & - & $15.3-62.6$ & 0.0150 & 2.93 & 0.97 & 0 \\
\hline \multirow{7}{*}{$\begin{array}{l}\tilde{a} \\
\tilde{\delta} \\
\stackrel{0}{0} \\
\tilde{D}\end{array}$} & Present study & Oran Bay Algeria & 111 & $14.4-24$ & $25.9-123.1$ & 0.0050 & $3.19 \pm 0.029$ & 0.94 & + \\
\hline & $\begin{array}{l}\text { Korichi, } 1988 \text { in } \\
\text { Djabali et al., } 1993\end{array}$ & $\begin{array}{l}\text { Bousmail Bay } \\
\text { Algeria }\end{array}$ & & & & 0.0097 & 3 & & \\
\hline & Petrakis and Stergiou, 1995 & Evvoikos Greece & 256 & $9.6-24.3$ & - & 0.0148 & 3.09 & 0.94 & 0 \\
\hline & Ceyhan et al., 2009 & Aegean Sea, Greece & 32 & $16.5-27.0$ & - & 0.0085 & $3.09 \pm 0.137$ & 0.94 & 0 \\
\hline & Sangun et al., 2007 & NE Mediterranean & 172 & $\begin{array}{c}11.20- \\
21.1 \\
\end{array}$ & $\begin{array}{l}10.66- \\
110.76 \\
\end{array}$ & 0.0072 & $3.08 \pm 0.096$ & 0.93 & 0 \\
\hline & Abdallah, 2002 & Egypt & 284 & $3.7-14.6$ & - & 0.007 & 3.13 & 0.97 & + \\
\hline & Cherif et al., 2008 & Tunis & 243 & $12-26$ & - & 0.007 & $3.06 \pm 0.027$ & 0.98 & 0 \\
\hline \multirow{10}{*}{ 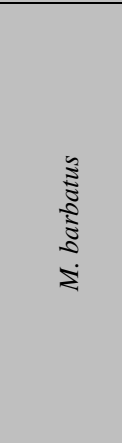 } & Present study & Oran bay Algeria & 369 & $109-232$ & $20.4-149.2$ & 0.022 & $2.84 \pm 0.028$ & 0.85 & - \\
\hline & Gökçe et al., 2007 & Turkey & 111 & $8-19.6$ & $6-90$ & 0.0091 & $3.10 \pm 0.10$ & 0.97 & + \\
\hline & Sangun et al., 2007 & Turkey & 451 & $8.2-22.0$ & $4.96-106.40$ & 0.0032 & $3.06 \pm 0.051$ & 0.94 & 0 \\
\hline & $\begin{array}{ll}\text { Moutopoulos } & \text { and } \\
\text { Stergiou, 2002 } & \end{array}$ & Kyclades & 15 & $19.1-29$ & - & 0.0177 & 2.83 & 0.75 & - \\
\hline & $\begin{array}{l}\text { Vassilopoulou and } \\
\text { Papaconstantinou,1992a }\end{array}$ & Aegean Sea & 438 & $7.5-17.5$ & - & 0.0073 & 3.28 & 0.97 & + \\
\hline & $\begin{array}{l}\text { Vassilopoulou and } \\
\text { Papaconstantinou, 1992a }\end{array}$ & Aegean Sea & 472 & $7.5-17.5$ & - & 0.0105 & 3.15 & 0.98 & + \\
\hline & Papaconstantinou et al., 1994 & Aegean Sea & 2206 & $5-24$ & - & 0.0000157 & 2.99 & 0.93 & 0 \\
\hline & Cherif et al., 2008 & Tunis & 1763 & $6.3-25$ & - & 0.005 & 3.23 & 0.99 & + \\
\hline & Gökçe et al., 2007 & Aegean Sea & 111 & $8-19.6$ & $6-90$ & 0.0091 & 3.1 & 0.97 & + \\
\hline & Abdallah, 2002 & Egypt & 512 & $3.6-15.7$ & - & 0.012 & 3 & 0.92 & 0 \\
\hline \multirow{7}{*}{ 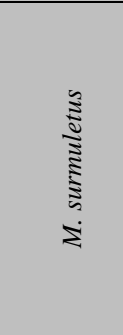 } & Present study & Oran Bay Algeria & 220 & $120-210$ & $20.7-108.2$ & 0.0000113 & $3.00 \pm 0.014$ & 0.97 & 0 \\
\hline & Ceyhan et al., 2009 & Turkey & 120 & $13.1-25.1$ & - & 0.0069 & $3.21 \pm 0.044$ & 0.97 & + \\
\hline & Gökçe et al., 2007 & Turkey & 38 & $7.3-18.6$ & $6-82$ & 0.0131 & $2.97 \pm 0.13$ & 0.98 & - \\
\hline & $\begin{array}{l}\text { Moutopoulos and } \\
\text { Stergiou., } 2002\end{array}$ & Kyclades & 257 & $13.8-32$ & - & 0.014 & 2.95 & 0.94 & 0 \\
\hline & $\begin{array}{l}\text { Moutopoulos and } \\
\text { Stergiou, } 1998\end{array}$ & Kyclades & 42 & $14-32$ & - & 0.0176 & 2.9 & 0.92 & 0 \\
\hline & $\begin{array}{l}\text { Vassilopoulou and } \\
\text { Papaconstantinou, 1992b }\end{array}$ & Aegean Sea & 451 & $10-20$ & - & 0.00909 & 3.25 & 0.97 & + \\
\hline & Abdallah, 2002 & Egypt & 122 & $5.4-20.8$ & - & 0.0110 & 3.03 & 0.73 & 0 \\
\hline \multirow{2}{*}{ T. picturatus } & Present study & Oran Bay Algeria & 94 & $14.2-23.5$ & $20.7-97.7$ & 0.0045 & $3.16 \pm 0.015$ & 0.96 & + \\
\hline & Merella et al., 1997 & Spain Balearic Islands & 180 & $4-23.9$ & - & 0.0089 & 2.86 & 0.99 & - \\
\hline \multirow{7}{*}{ 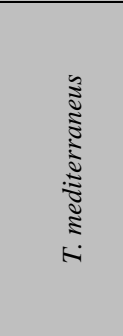 } & Present study & Oran bay Algeria & 1795 & $13.2-35$ & $16.9-344.4$ & 0.0058 & 3.09 & 0.94 & 0 \\
\hline & Korichi, 1988 in & Bousmail Bay & - & - & - & $0.01420 \mathrm{~F}$ & 3 & - & 0 \\
\hline & Djabali et al., 1993 & Algeria & - & - & - & $0.01270 \mathrm{M}$ & 3 & - & 0 \\
\hline & Cherif et al., 2008 & Tunis & 462 & $8.8-30$ & - & 0.007 & 3.01 & 0.99 & 0 \\
\hline & $\begin{array}{l}\text { Moutopoulos and } \\
\text { Stergiou., } 2002\end{array}$ & Kyclades & 191 & $17.3-34.1$ & - & 0.0144 & 2.82 & 0.92 & - \\
\hline & Pešić et al., 2012 & Montenegro & 730 & $8.9-31.3$ & - & $\begin{array}{l}0.0073 \mathrm{M} \\
0.0088 \mathrm{~F} \\
\end{array}$ & $\begin{array}{l}3.02 \\
2.95 \\
\end{array}$ & $\begin{array}{l}- \\
- \\
\end{array}$ & $\begin{array}{l}0 \\
- \\
\end{array}$ \\
\hline & Ozdemir and Duyar, 2013 & Turkey & 526 & $9.4-15.1$ & $4.6-25.2$ & 0.0032 & 3.30 & 0.89 & + \\
\hline \multirow{5}{*}{ 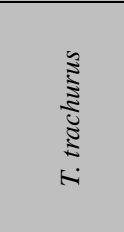 } & Present study & Oran bay Algeria & 769 & $13.8-20.3$ & $18.7-60.7$ & 0.0031 & 3.29 & 0.93 & + \\
\hline & Korichi, 1988 in & Bousmail Bay & - & - & - & $0.001270 \mathrm{M}$ & 3 & - & 0 \\
\hline & Djabali et al., 1993 & Algeria & - & - & - & $0.001500 \mathrm{~F}$ & 3 & - & 0 \\
\hline & Cherif et al., 2008 & Tunis & 229 & $9-32$ & - & 0.007 & 2.98 & 0.99 & 0 \\
\hline & $\begin{array}{l}\text { Moutopoulos and } \\
\text { Stergiou, } 2002\end{array}$ & Kyclades & 12 & $15.8-28$ & - & 0.00339 & 3.27 & 0.96 & + \\
\hline
\end{tabular}

$\mathrm{n}$ : sample size, a: intercept, b:slope, s.e (b): standard error of $b, r^{2}$ :coefficient of determination, All: allometry ( 0: isometric, -: negative allometeric, + : positive allometric). 
Froese (2000) has suggested that a plot of log a versus b (Fig.3) for all known weight- length relationships of a species results in a linear relationship, and this relationship can be used to identify outliers. In this paper, we have applied this method to all species. This led to the detection of outliers, where the respective point deviated more than two standard deviations from the regression line. One outlier was detected for B.boops and one for $M$. barbatus off the seven studied species.
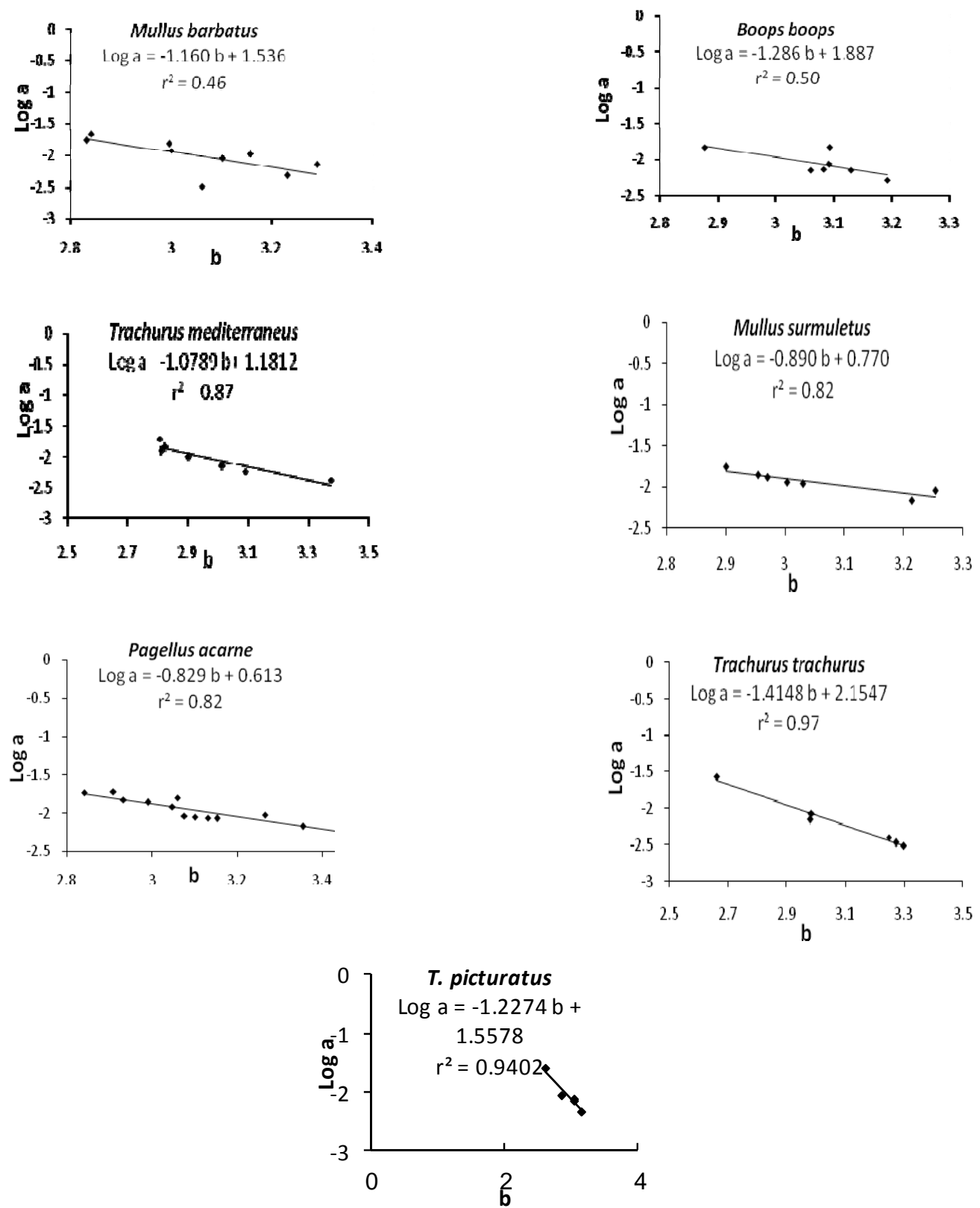

Fig. 3. Plots of log a versus $b$ for available weight- length relationships of seven fish species in the Mediterranean waters. 
However, these results are important by the fact that they contribute to enrich the available data on species living in the Mediterranean and constitute the first reference on W-L relationships for four species from Algerian waters (Pagellus acarne; Mullus barbatus; Mullus surmuletus; Trachurus picturatus).

\section{Conclusion}

For Algerian waters, scarce data exist on the relation between weight and length for species cited previously we can cite works of Korichi 1988 (T. mediterraneus and T. trachurus) and Chali-Chabane, 1988 (B. boops). Concerning Oran Bay data are presented for the first time in this paper helping comparative studies in this field to explain differences in growth trend (WL) found between different fish populations. Further studies will target a large number of species occupying the area to understand the inter-population and shape variations using the outliers method.

\section{Acknowledgements}

The authors would like to thank LRSE and AQUABIOR laboratory teams for their precious help during the samples collection and investigation.

\section{References}

Abdallah, M. (2002). Length-Weight Relationship of Fishes Caught by Trawl off Alexandria, Egypt. Naga, the ICLARM Quarterly, 25(1) January-March: 19-20.

Andrade, H.A. and Campos, R.O. (2002). Allometry coefficient variations of the length-weight relationship of skipjack tuna (Katsuwonus pelamis) caught in the southwest South Atlantic. Fisheries Research., 55, $307-$ 312 .

Bensahla Talet, A. and Boutiba, Z. (2000) La pêche à Oran de 1995 à 1999. Actes des $4^{\text {èmes }}$ journées tunisiennes des sciences de la mer: 17-19 novembre 2000, Mehdia (Tunisie).18-23 p.

Beverton, R.J.H. and Holt, S.J. (1996) On the Dynamics of Exploited Fish Populations. Chapman and Hall. London, $533 \mathrm{p}$

Ceyhan, T., Akyol, O. and Erdem, M. (2009) Length-Weight Relationships of Fishes from Gökova Bay, Turkey (Aegean Sea). Turkish Journal of Zoology. 33: 69-72.
Chali-Chabane, F. (1988). Contribution à l'étude biologique et dynamique de bogues, Boops boops (Linné, 1758) de la baie de Bou-Ismail. Thèse de Magister. Ministère aux Universités, Institut des Sciences de la Mer et de l'aménagement du Littoral, Alegria. $111 \mathrm{p}$.

Cherif, M., Zarrad, R., Gharbi, H., Missaoui, H. and Jarboui, O. (2008) Length-weight relationships for 11 fish species from the Gulf of Tunis (SW Mediterranean Sea, Tunisia). Pan-American Journal of Aquatic Sciences, 3 (1): $1-5$

Djabali, F., Mehailia, A. Koudil, M. and Brahmi, B., (1993). Empirical equations for the estimation of natural mortality in Mediterranean teleosts. Naga ICLARM Quarterly. 16(1):35-37.

Dulcic, J. and Kraljevic, M. (1996) Weight-length relationships for 40 fish species in the eastern Adriatic (Croatian waters). Fisheries Research, 28: 243-251.

Froese, R. (2006). Cube law, condition factor and weightlength relationships: history, meta-analysis and recommendations. Journal of applied ichthyology, 22(4): 241-253.

Froese, R. (2000). Evaluating length-weight relationships. In: FishBase 2000: Concepts, Design and Data Sources. R. Froese and D. Pauly (Eds). ICLARM, Los Baños, Laguna, Philippines, p. 133.

Gökçe, G., Aydin, I. and Metin, C. (2007) Length-weight relationships of 7 fish species from the North Aegean Sea,Turkey. International Journal of Nature and Engineering. Sciences, 1: 51-52 (2007).

Gonçalves, J.M.S., Bentes, L., Lino, P.G., Ribeiro Canário, A.V.M. and Erzini, K. (1997) Weight-length relationships for selected fish species of the small-scale demersal fisheries of the south and south-west coast of Portugal. Fisheries Research, 30:253-256.

Kolher, N., Casey, J. and Turner, P. (1995) Length-weight relationships for 13 species of sharks from the western North Atlantic. Fisheries Bulletin, 93: 412-418.

Korichi, H.S. (1988) Contribution à l'étude biologique des deux espèces de saurels: Trachurus trachurus (Linné, 1758) et Trachurus mediterraneus (Steindachner, 1868) et de la dynamique de Trachurus trachurus (Linné, 1758) en baie de Bou-Ismail (Alger). Thèse de Magister. ISMAL. Alger. 203 p.

Merella, P., Quetglas, A., Alemany, F. and Carbonell, A. (1997) Length-Weigth relationship for fishes and cephalopods from the Balearic Islands (Western Mediterranean). NAGA. The ICLARM Quarterly. JulyDecember $1997.3 \mathrm{p}$.

Morey, G., Moranta, J., Massuti, E., Grau A., Linde, M., Riera, F. and Morales-Nin, B. (2003) Weight-length relationships of littoral to lower slope fishes from Western Mediterranean. Fisheries Research. 62: 89-96.

Moutopoulos, D.K. and Stergiou, K.I. (1998) Length-weight 
and length relationships for seven fish species of the Aegean Sea. Proceedings of the $20^{\text {th }}$ meeting of the Hellenic Society of Biological Sciences, 20: 207-208.

Moutopoulos, D.K. and Stergiou, K.I. (2002). Length-weight and length-length relationships of fish species from the Aegean Sea (Greece). Journal of Applied Ichthyology. 18 (2002), 200-203.

Ozdemir, S. and Duyar, H.A. (2013). Length-Weight Relationships for Ten Fish SpeciesCollected by Trawl Surveys from Black Sea Coast, Turkey. International Journal of Chemical, Environmental \& Biological Sciences (IJCEBS), 1(2): 405-407.

Papaconstantinou, C., Politou, C.Y., Caragitsou, E., Stergiou, K.I., Mytilineou, CH., Vassilopoulou, V., Fourtouni, A., Karkani, M., Kavadas, S., Petrakis, G., Siapatis, A., Chatzinikolaou, P. and Giagnisi, M. (1994). Investigations on the abundance and distribution of demersal stocks of primary importance in the Thermaikos Gulf and the Thracian Sea (Greece). National Centre for Marine Research, Athens, Greece, Technical Report, North Aegean Series 4/ 1994, 356 p.

Pauly, D. (1993). Fishbyte Section. Editorial. Naga. ICLARM Quart. 16: 26.

Pešić, A., Joksimović, A., Đurović, D., Mandic, M., Marković, O. and Ikica, Z. (2012). Biological Characteristic of Mediterranean Horse Mackerel (Trachurus Mediterraneus, Steindachner, 1868) from the Montenegrin Shelf (Southern Adriatic). Water Resource Management, 2(3): 29-33.
Petrakis, G. and Stergiou, K.I. (1995). Weight-length relationships for 33 fish species in Greekwaters. Fisheries Research, 21:465-469.

Sangun, L., Akamca, E. and Akar, M. (2007). WeightLength Relationships for 39 Fish Species from the NorthEastern Mediterranean Coast of Turkey. Turkish. Journalof Fisheries and Aquatic Sciences, 7: 37-40.

Sinovcic, G., Franicevic, M., Zorica, B. and Ciles-Kec, V. (2004). Length-weight and length-length relationships for 10 pelagic fish species from the Adriatic Sea (Crotia). Journal of Applied Ichthyology, 20: 156-158.

Ricker, W.E. (1973). Linear regressions in fishery research. Journal of Fisheries Research. Board Can.30: 409-434.

Ritcher, H., Luckstadt, C., Focken, U. and Becker, K. (2000). An improved procedure to assess fish condition on the basis of length-weight relationships. Archive of Fishery and Marine Research, 48: 255-264.

Sparre, P., Ursin, E. and Venema, S.C. (1989) Introduction to tropical fish stock assessment. Part I. Manual. FAO Fisheries Technical Paper No. 306.

Vassilopoulou, V. and Papaconstantinou, C. (1992a) Aspects of the biology of red mullet (Mullus barbatus) in the Aegean Sea. FAO Fisheries Report 477:115-126.

Vassilopoulou, V. and Papaconstantinou, C. (1992b). Preliminary biological data on the striped red mullet (Mullus surmuletus) in the Aegean Sea. FAO Fisheries Report 477:85-96. 


\section{علاقات الوزن - الطول لسبعة أنواع من الأسمالك (عظميات: سباريداي، وموليداي،

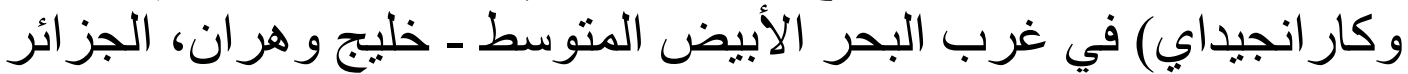

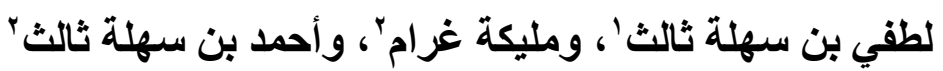

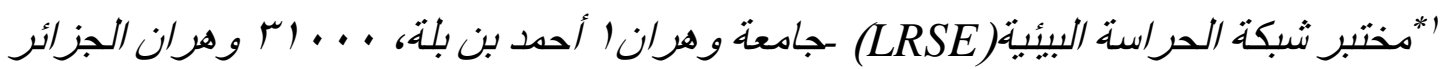

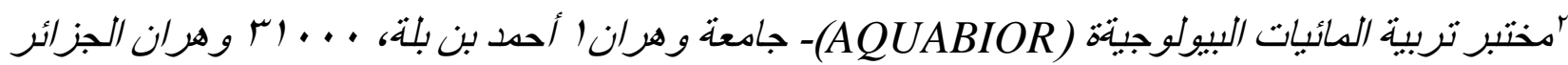 *btlotfi77@hotmail.fr}

المستلخص. لا توجد معلومات حالبا عن علاقات الطول بالوزن لعائلة سباريداي: المرجان

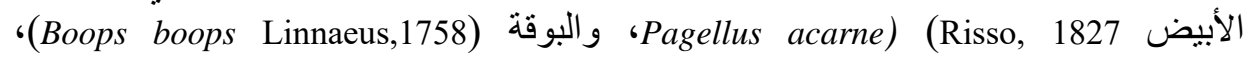

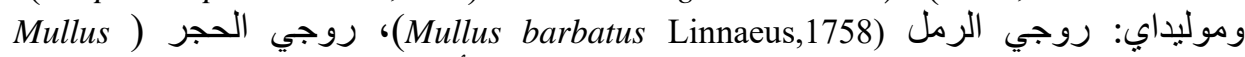

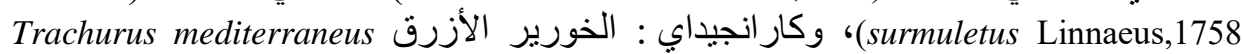

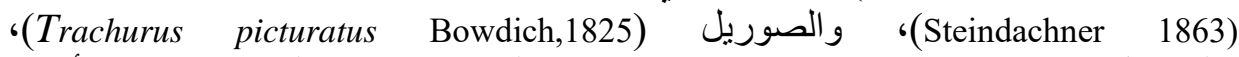
و الخوريل (Trachurus trachurus, Linnaeus 1758) المستخرجة من خليج وهر الان فئ في الأبيض

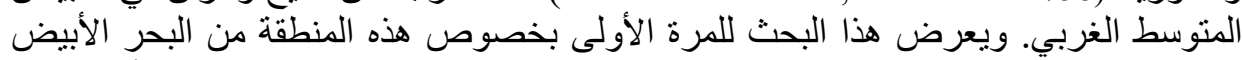

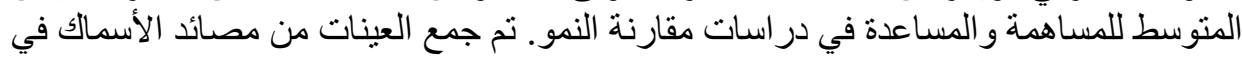

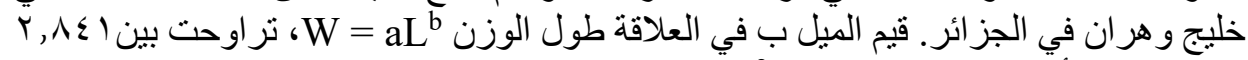

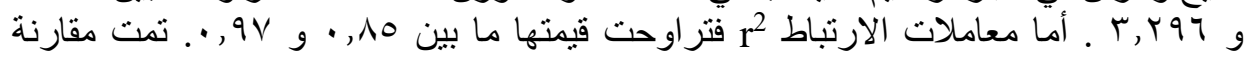

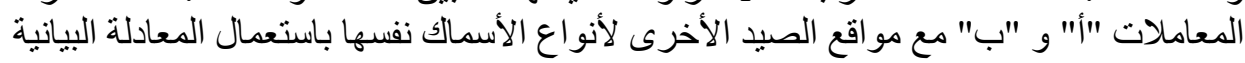

.[Froese plot Log a=f(b)]

Trachurus picturatus; Trachurus mediterraneus; الكلمات الدالة: علاقة الطول بالوزن Trachurus trachurus; Mullus surmuletus; Mullus barbatus; Boops

boops; Pagellus; acarne; 